\title{
Economic Appraisal of Bio-Priming Mediated Stress Moderation in Crop Plants
}

\section{O. Shiva Devika and Amitava Rakshit"}

Department of Soil Science and Agricultural Chemistry, Institute of Agricultural Sciences, Banaras Hindu University, Varanasi-221005, Uttar Pradesh, India

"Corresponding author: amitavar@bhu.ac.in (ORCID ID: 0000-0002-9406-8262)

Received: $12-04-2019$

Revised: $14-07-2019$

Accepted: 23-08-2019

\begin{abstract}
The primary restraint in crop production and food security worldwide is exposure of crop to stress conditions viz., abiotic and biotic which has driven the attention of scientists. Stress conditions induce changes in plant internal functions leads to reduction in plant growth and yield. The adverse economic losses due to abiotic stresses can be mitigated by application of chemicals such as anti-transpirants, nutrients and plant growth regulators, while the biotic stresses by application of pesticides and fungicides. Another way to resist stress conditions is adoption of modern breeding technologies and biotechnological strategies to produce climate resilient crops. Promotion of chemicals and biotechnology tools negatively impacts soil health, environment as well as socio-economic status of the farmer. Though the use of agro-chemicals is unavoidable in modern agriculture, indiscriminate use of chemicals would cause imbalance in environment and reduction in benefit to cost ratio (B: C) of farmer. In this context to make the crop production profitable, the review has outlined different economic considerations associated with biopriming mediation for stress moderation in different crop plants.
\end{abstract}

\section{Highlights}

( Multiple stress due to climate change during crop production can be mitigated through the invention of seed bio-priming.

( Bio-priming intervention can supplement a part of inputs needed for crop production thus reduce the investment.

( Bio-priming can improve both quality and quantity of produce and enhance B : C ratio as compared with solely RDF.

Keywords: Biotic stress, abiotic stress, bio-priming, B : C ratio

\section{Importance of bio-priming in the present perspective of changing climate}

Climate change is a shift in pattern of regional or global climate which is predominantly caused by anthropogenic activities. Global warming is phenomenon of climate change leads to raise in average temperature of the earth and is directly related to green house gas emissions, fossil fuels, deforestation, intensive farming etc. (Fig. 1.)

As agriculture is highly dependent on climatic conditions, it is interconnected with climate change. Climate change alters agriculture in numerous manners including increase in temperature, change in rainfall and extreme weather conditions.

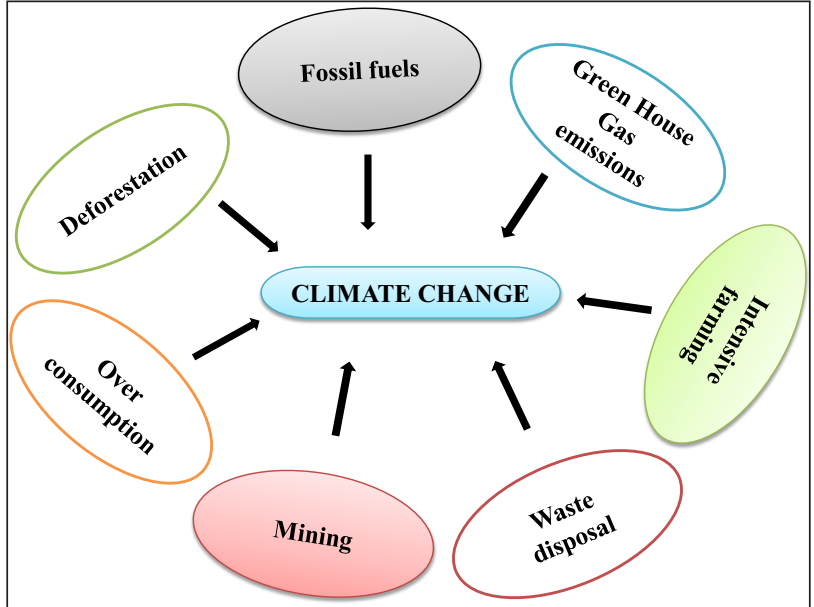

Fig. 1: Causes for climate change 
AESRA

These weather situations leaves the crop under stress, favours the attack of pest and diseases and also degrades the quality of the produce. In this scenario, to mitigate the effects of climate change and to ensure food security, well suited technique is conventional breeding and genetic engineering approaches which is not economical and practically feasible. The alternative method which is eco friendly, low cost intensive for secured yield even under adverse climatic conditions is bio-priming.

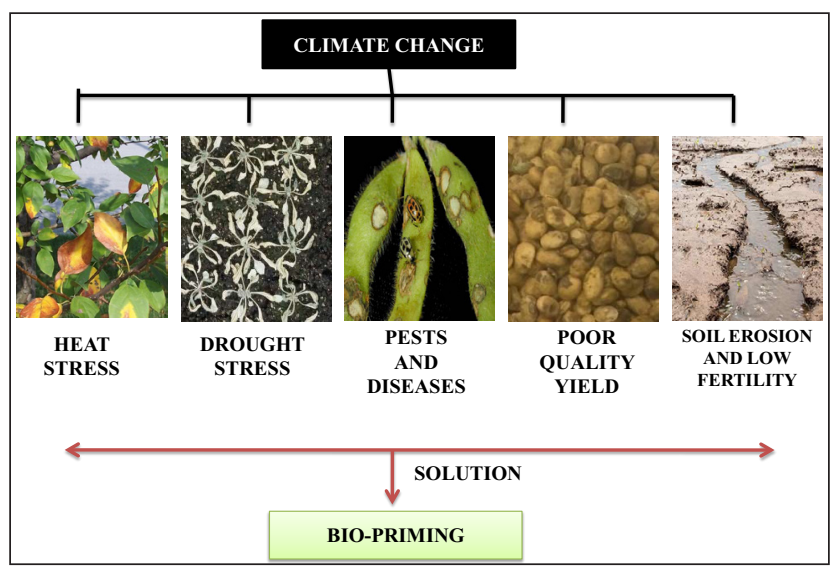

Fig. 2: Effect of climate change in agriculture

Bio-priming is a process of biological seed treatment that refers combination of seed hydration (physiological aspect of disease control) and inoculation (biological aspect of disease control) of seed with beneficial organism to protect seed (Rakshit et al. 2014). Bio-priming improves germination rate, uniformity in plant population, increases water and nutrient use efficiency, eliminates seed borne pathogens, controls pests and diseases. Besides these advantages, bio-priming reduces the hazardous effects on humans caused by the use of fungicides, bactericides and pesticides by supplementing a part of chemical usase (Fig. 3).

Bio-priming with Trichoderma in soybean enhanced both macro and micro nutrient use efficiency (Entesari et al. 2013; Santiago et al. 2012) and in mustard, the over all performance of the crop with reference to yield and buffering capacity of crop against abiotic stresses is improved (Karthika et al. 2012; Lalitha et al. 2012). Pseudomonas isolates controls soil-borne phyto pathogens (O'Callaghan et al. 2006), it controlled alternaria blight in sunflower and showed least disease indices i.e., 19.24, 28.86 and $37.74 \%$ at 45,60 and 75 DAS respectively (Rao, et al. 2009). Priming the sesame seed with
Trichoderma harzianum successfully controlled the charcoal rot disease (Macrophomina phaseolina) (El-Fiki et al. 2004). Seed bio-priming defends the plants against several adverse conditions like pest and disease attack. Seed priming of cucumber seeds with bacteria Bacillus gaemokensis defended the plant against both pathogen viz., Pseudomonas syringae and herbivore viz., Spodoptera litura by producing jasmonic acid in leaves. This induced plant resistant was mainly due to the cyclo-dipepides (L- leu, P pro) present in Bacillus and is a promising technique for protecting plant against biotic stress conditions (Song et al. 2017).

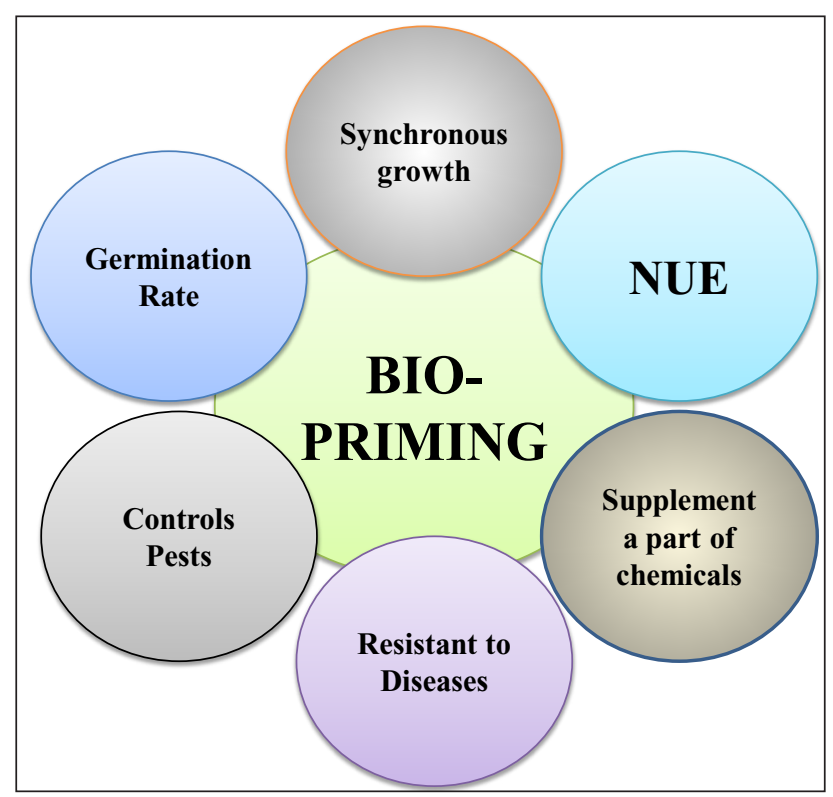

Fig. 3: Different facets of bio-priming

Priming ground nut seed with Pseudomonas fluorescens resist the crop against salt stress (Saravanakumar \& Samiyappan, 2007). Tolerance to heat stress was observed in soybean by biopriming seed with Serratia proteamaculan (Dimkpa et al. 2005). Inoculation of maize seed with Azospirillum brasilense recorded improved relative and absolute water content as compared to non primed plants and the results were more significant at $75 \%$ reduction in water supply than $50 \%$ reduction (Casanovas et al. 2002).

In course of time, along with change in climate plant have to pass through several adverse conditions such as abiotic and biotic stresses which affects crop performance. Over the past few years, priming, particularly seed priming has emerged as a promising strategy in modern stress (biotic and 


\begin{tabular}{|c|c|c|c|c|c|c|c|c|}
\hline & 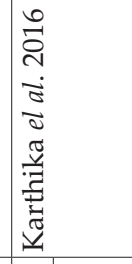 & 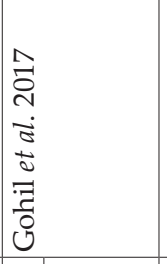 & 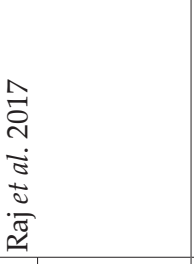 & 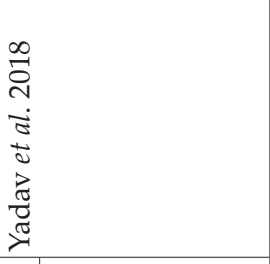 & 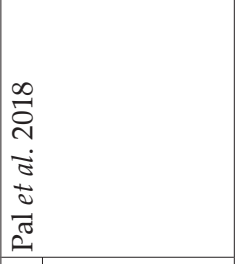 & 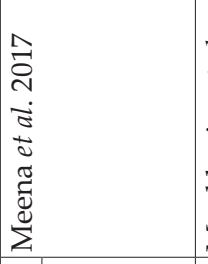 & 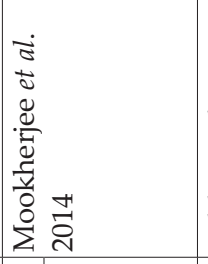 & 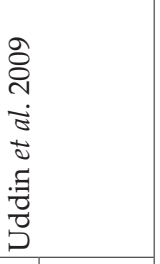 \\
\hline 0 & 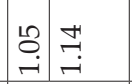 & 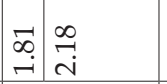 & $\stackrel{\sim}{-} \overrightarrow{\mathrm{i}}$ & 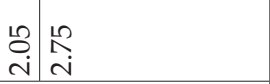 & $\underset{\stackrel{i}{i}}{\stackrel{\vec{d}}{\mathrm{i}}}$ & $\begin{array}{lll}m_{i} & \stackrel{i}{i} \\
\end{array}$ & 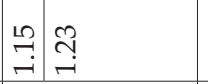 & 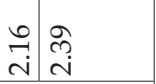 \\
\hline & 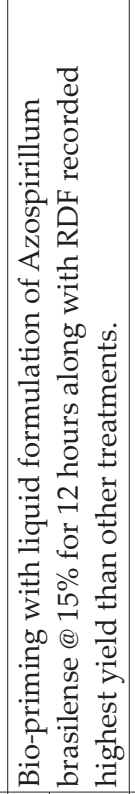 & 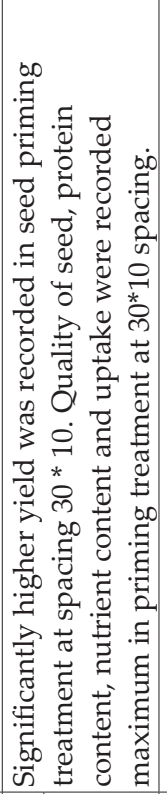 & 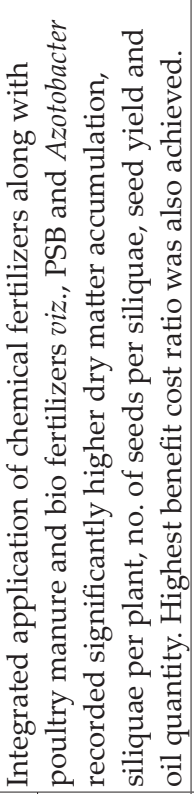 & 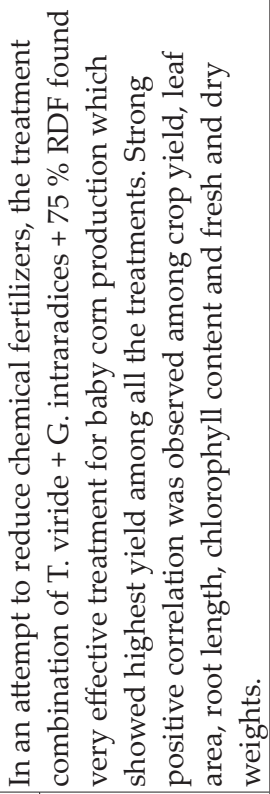 & 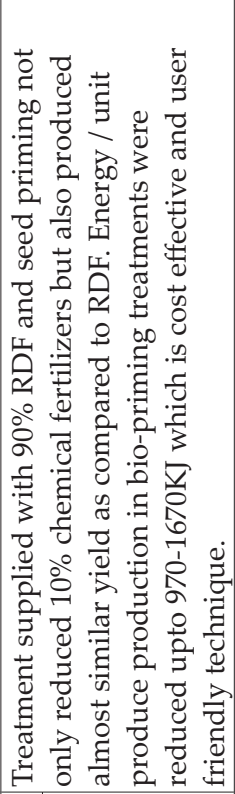 & 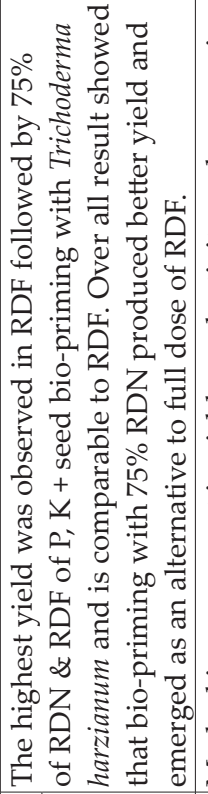 & 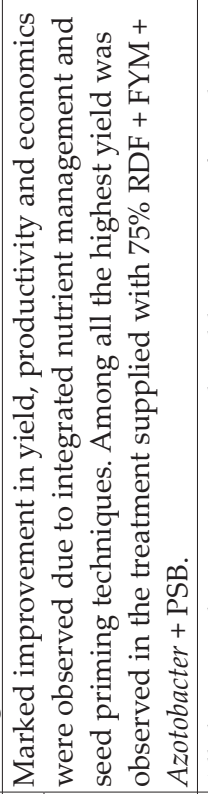 & 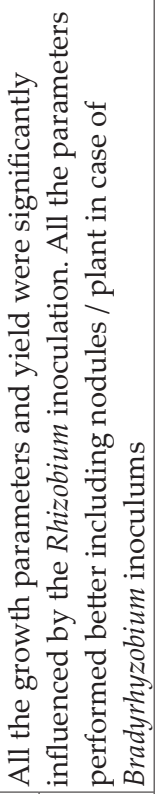 \\
\hline
\end{tabular}

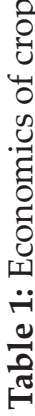

\begin{tabular}{|c|c|c|c|c|c|c|c|c|}
\hline 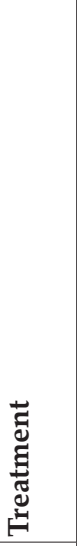 & 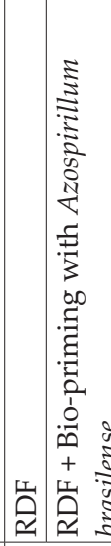 & 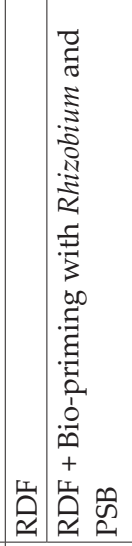 & 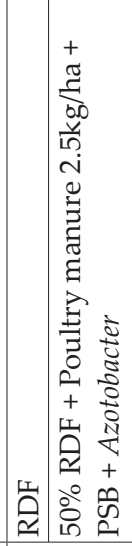 & 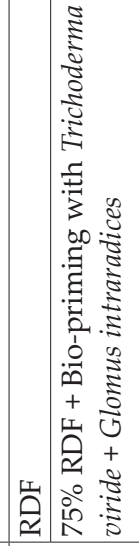 & 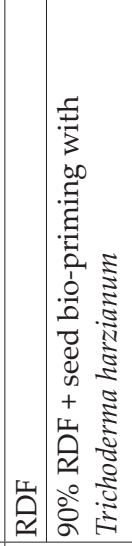 & 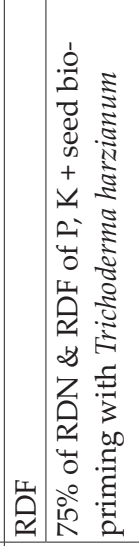 & 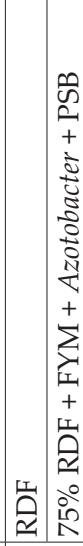 & 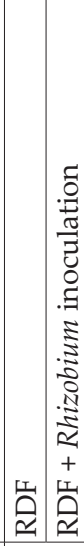 \\
\hline 足 & $\frac{\pi}{\tilde{0}}$ & 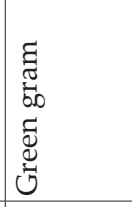 & 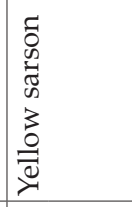 & $\begin{array}{l}\Xi \\
0 \\
0 \\
\overrightarrow{0} \\
\tilde{\Xi} \\
\infty\end{array}$ & $\frac{\pi}{\tilde{0}}$ & $\frac{\pi}{\tilde{\Xi}}$ & 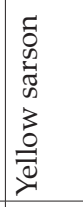 & 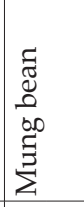 \\
\hline 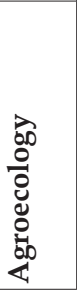 & 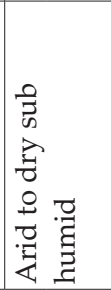 & 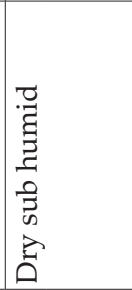 & 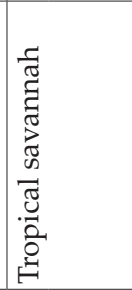 & 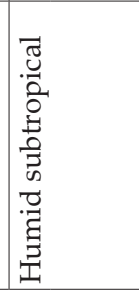 & 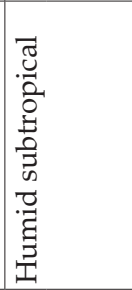 & 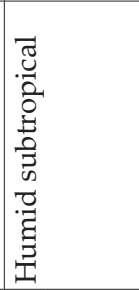 & 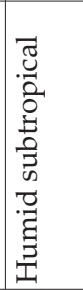 & 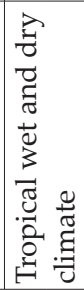 \\
\hline$\dot{\omega} \dot{z}$ & $\rightarrow$ & $a$ & $m$ & H & in & 6 & $\Lambda$ & $\infty$ \\
\hline
\end{tabular}




\begin{tabular}{|c|c|c|c|c|c|c|c|c|c|c|c|c|c|}
\hline 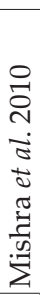 & & 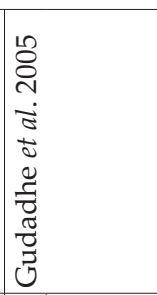 & 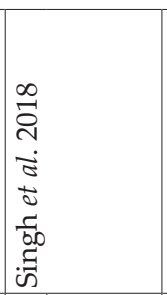 & 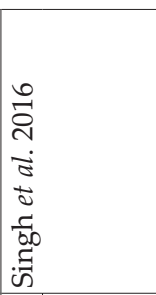 & 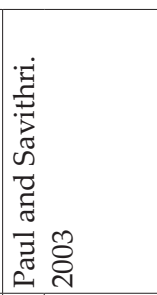 & 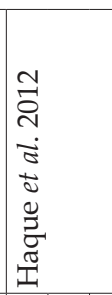 & & 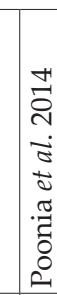 & & 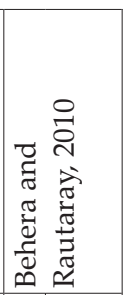 & 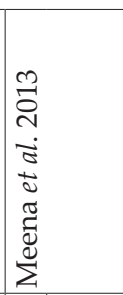 & 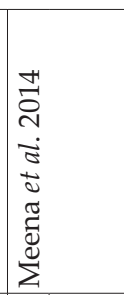 & 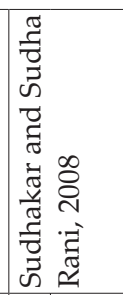 \\
\hline న్ & $\underset{⿱}{i}$ & 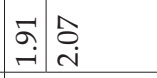 & 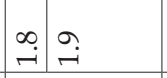 & 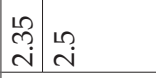 & 苫 & 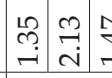 & †ำ & 年 & ت & \begin{tabular}{|l|l}
$\triangleright$ & 0 \\
$\infty$ & $\stackrel{1}{1}$ \\
$i$ & i \\
\end{tabular} & 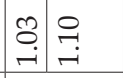 & 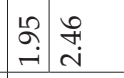 & 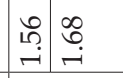 \\
\hline 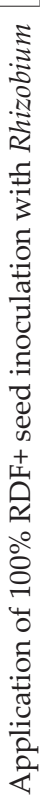 & 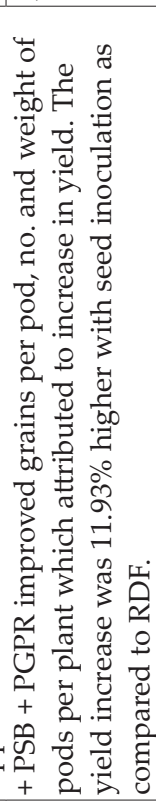 & 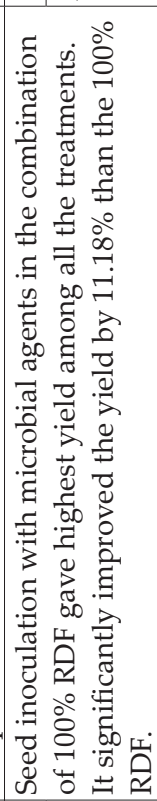 & 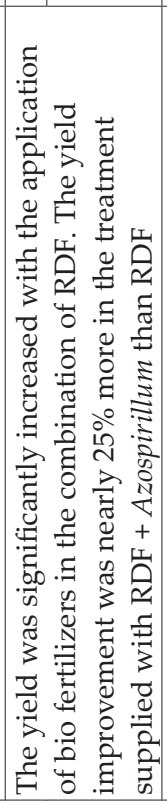 & 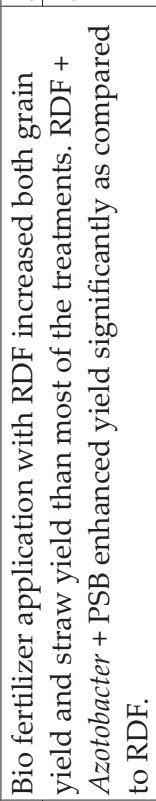 & 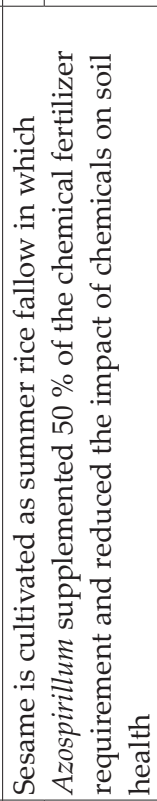 & 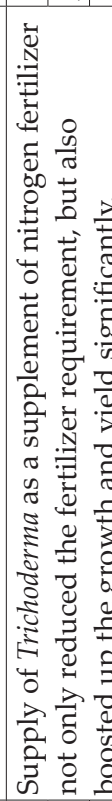 & 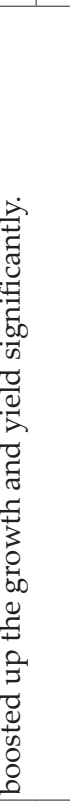 & & 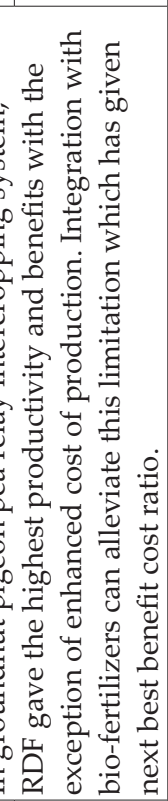 & 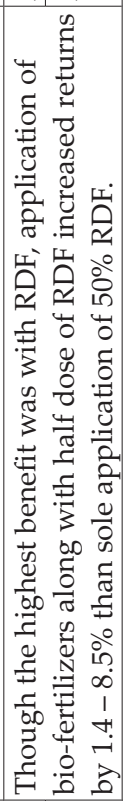 & 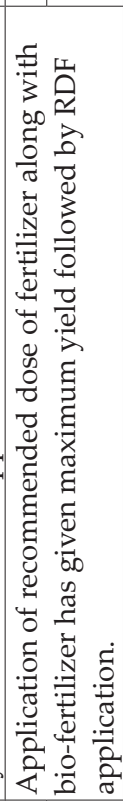 & 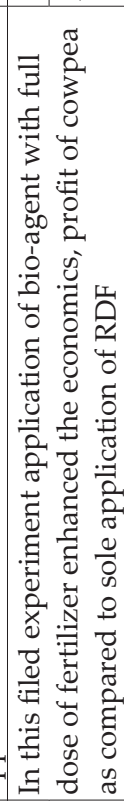 & 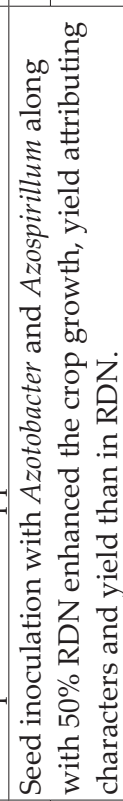 \\
\hline
\end{tabular}

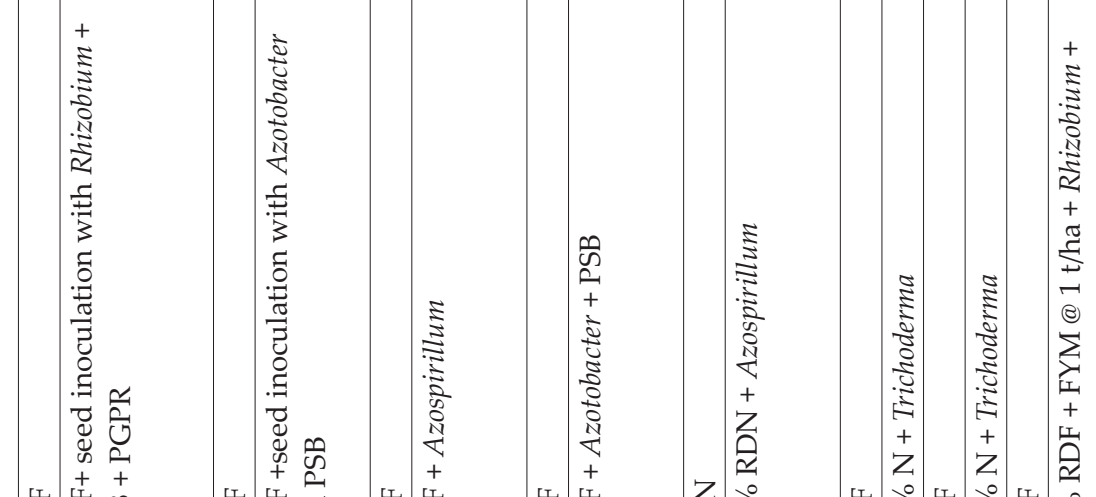

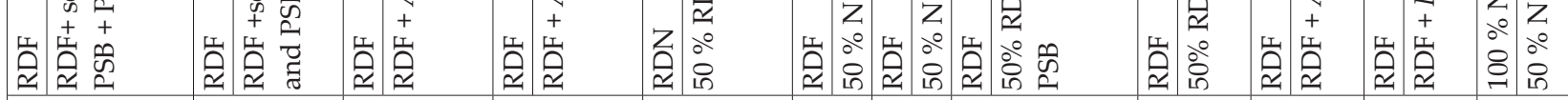

\begin{tabular}{|c|c|c|c|c|c|c|c|c|c|c|c|}
\hline 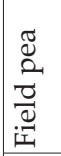 & $\begin{array}{l}\bar{J} \\
\bar{\pi} \\
\bar{w} \\
\sum \\
\sum\end{array}$ & 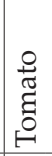 & $\begin{array}{l}\frac{\vec{\Xi}}{3} \\
\frac{\pi}{3}\end{array}$ & 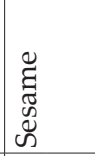 & 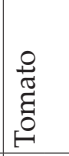 & 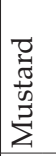 & 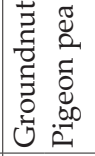 & $\begin{array}{l}\text { 离 } \\
\frac{\tilde{m}}{3}\end{array}$ & 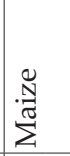 & 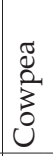 & 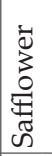 \\
\hline 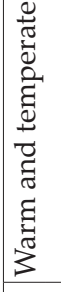 & 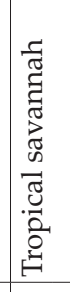 & 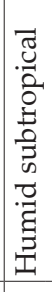 & 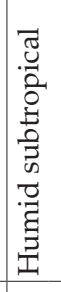 & 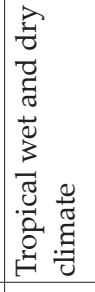 & 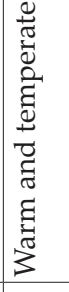 & 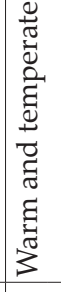 & 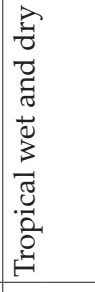 & 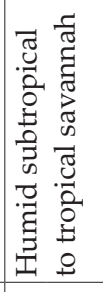 & 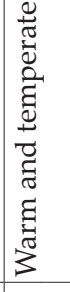 & 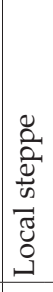 & 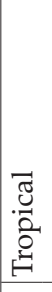 \\
\hline$\sigma$ & 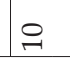 & $F$ & $\approx$ & 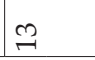 & $\exists$ & $\stackrel{2}{\sim}$ & 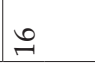 & 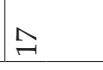 & $\stackrel{\infty}{\sim}$ & 2 & तิ \\
\hline
\end{tabular}


abiotic) management as it protects plants against pathogens and abiotic stresses without heavily affecting fitness (Van Hulten et al. 2006).

\section{Cost of cultivation methodology}

The secondary data used in this study were collected from several research evidences. Concepts used in the study:

(a) Benefit cost ratio (BCA): It is an approach to evaluate a project or investment by comparing economic benefits with economic costs. BCA is calculated as value of benefits divided by value of costs at the time of respective experiments conducted.

$$
B C R=\frac{\sum_{t=0}^{T} \frac{B_{t}}{(1+r)^{t}}}{\sum_{t=0}^{T} \frac{C_{t}}{(1+r)^{t}}}
$$

$B_{t}$ is the benefit at time $t$ and $C_{t}$ is the measure of costs at time $t$.

\section{(b) Conversion of yield/plant to yield/ha:}

No. of plants $=10,000 \mathrm{~m}^{2} /$ product of spacing in $\mathrm{m}^{2}$. Simple statistical and arithmetic tools such as averages, percentages and ratios were worked out.

\section{Economic appraisal of different crops under varied agro ecology}

Agro ecology is the application of ecological concepts and principles to the design and management of sustainable agricultural systems (Gliessman, 1992). India is comprised of heterogeneous landforms with varying environmental situations resulted in variety of soils. Under these varying conditions, for getting assured production farmers are applying plenty amount of fertilizers, pesticides and herbicides, this choice overloaded the farmers economically. The economic impacts of stress conditions can be complex and may lead to less benefit to the farmers.

Rapidly expanding population puts ample burden on the natural assets, and hence it is necessary to adopt eco-friendly and efficient methods. By keeping all these in view, adopting microbial agents in agriculture can be suggested as an alternative to the varying environmental situations and for sustainable use of natural resources (Table 1).

\section{CONCLUSION}

Climate change is giving negative impact on agriculture and imposing an economic penalty. In agriculture dependent countries like India, sustainable production technologies to mitigate climate change is necessary and prerequisite. Climate change leads to exposure of plant to multiple stress conditions causes unpleasant changes in functioning of plant, ultimately leads to deleterious effect on quality and quantity of produce. To overcome this problem farmers are using plenty of agro-chemicals which over loaded the farmer economically and resulted in reduction in the benefit to cost ratio. To reduce the burden on the natural resources, input cost to farmers and for getting assured production, adoption of eco-centric and user friendly techniques like biopriming is necessary. Bio-priming improves plant performance even under adverse environmental conditions by several means such as improving germination percentage, resist the plant against both biotic and abiotic stresses, supplements part of the chemical use. Besides these, bio-priming assures sustainability, yield and it also increases benefit to cost ratio compared to conventional practices.

\section{REFERENCES}

Bairwa, R.K., Nepalia, V., Balai, C.M., Jalwania, R. and Meena, H.P. 2014. Yield and nutrient uptake of summer green gram [Vigna radiata $(\mathrm{L})$ Wilczek] under different levels of phosphorus and Sulphur fertilizations. SAARC Journal of Agriculture, 12(1): 162-172.

Behera, U.K. and Rautaray, S.K. 2010. Effect of biofertilizers and chemical fertilizers on productivity and quality parameters of durum wheat (Triticum turgidum) on a Vertisol of Central India. Archives of Agronomy and Soil Science, 56(1): 65-72.

Casanovas, E.M., Barassi, C.A. and Sueldo, R.J. 2002. Azospirillum inoculation mitigates water stress effects in maize seedlings. Cereal Research Communications, 30: 343-350.

Dimkpa, C., Weinand, T. and Asch, F. 2009. Plant-rhizobacteria interactions alleviate abiotic stress conditions. Plant, Cell and Environment, 32: 1682-1694.

El-Fiki, A.I.I., Mohamed, F.G., El-Deeb, A.A., and Khalifa, M.M.A. 2004. Some applicable methods for controlling sesame charcoal rot disease (Macrophomina phaseolina) under greenhouse conditions. Egypt. J. Phytopathol., 32(12): 87-101.

Entesari, M., Sharifzadeh, F., Ahmadzadeh, M. and Farhangfar, M. 2013. Seed biopriming with Trichoderma Species and Pseudomonas fluorescent on growth parameters, enzymes 
AESRA

activity and nutritional status of soybean. International Journal of Agronomy and Plant Production, 4(4): 610-619.

Gliessman, S.R. 1992 Agroecology in the tropics: achieving a balance between land use and preservation. Environ. Mngt., 16: 681-689.

Gudadhe, N.N., Mankar, P.S., Khawale, V.S. and Dongarkar, K.P. 2005. Effect of biofertilizers on growth and yield of mustard (Brassica juncea L.). Journal of Soils and Crops, 15(1): 160-162.

Haque, M.M., Ilias, G.N.M. and Molla, A.H. 2012. Impact of Trichoderma-enriched biofertilizer on the growth and yield of mustard (Brassica rapa L.) and tomato (Solanum lycopersicon Mill.). The Agriculturists, 10(2): 109-119.

Karthika, C. and Vanangamudi, K. 2012. Biopriming of maize hybrid $\mathrm{COH}(\mathrm{M}) 5$ seed with liquid biofertilizers for enhanced germination and vigour. African Journal of Agricultural Research, 8(25): 3310-3317.

Karthika, C., Vanangamudi, K. and Nagendran, K. 2016. "Influence of seed biopriming and organic manure nutrition on okra organic seed production." Advance Research Journal of Crop Improvement 7(1): 1-9.

Lalitha, P., Srujana and Arunalakshmi, K. 2012. Effect of Trichoderma viride on germination of mustard and survival of mustard seedlings. International Journal of Life Sciences Biotecthnology and Pharma Research, 1(1): 137-140.

Meena, J.S., Verma, H.P. and Pancholi, P. 2014. Effect of fertility levels and biofertilizers on yield, quality and economic of cowpea. Agriculture for Sustainable Development, 2(2): 162-164.

Meena, M.D., Tiwari, D.D., Chaudhari, S.K., Biswas, D.R., Narjary, B., Meena, A.L. and Meena, R.B. 2013. Effect of biofertilizer and nutrient levels on yield and nutrient uptake by maize (Zea mays L.). Annals of Agri-Bio Research, 18(2): 176-181.

Meena, S.K., Rakshit, A., Singh, H.B. and Meena, V.S. 2017. Effect of nitrogen levels and seed bio-priming on root infection, growth and yield attributes of wheat in varied soil type. Biocatalysis and Agricultural Biotechnology, 12: 172-178.

Mishra, A., Prasad, K. and Rai, G. 2010. Effect of bio-fertilizer inoculations on growth and yield of dwarf field pea (Pisum sativum L.) in conjunction with different doses of chemical fertilizers. Journal of Agronomy, 9(4): 163-168.

Mookherjee, S., Malik, G.C., Bandyopadhyay, S. and Mitra, B. 2014. The productivity of Brassica rapa var. yellow sarson as influenced by integrated nutrient management practices and seed priming in Eastern Indian subHimalayan plains. SAARC Journal of Agriculture, 12(1): 106-116.

O'Callaghan M., Swaminathan, Lottmann, J., Wright, D. and Jackson, T.A. 2006. Seed coating with biocontrol strain Pseudomonas fluorescens F113. NZ Plant Prot., 59: 80-85.

Pal, S. and Singh, H.B. 2018. Energy Inputs and Yield Relationship in Greenhouse Okra Production by Biopriming. International Journal of Agriculture, Environment and Biotechnology, 11(5): 741-746.
Paul, I.K. and Savithri, K.E. 2006. Effect of biofertilizers vs perfected chemical fertilization for sesame grown in summer rice fallow. Journal of Tropical Agriculture, 41: 47-49.

Poonia, T.C., Raj, A.D. and Pithia, M.S. 2014. Effect of organic, inorganic and biofertilizers on productivity and economics of groundnut-pigeonpea relay intercropping system in vertisols of Gujarat. Journal of Experimental Biology and Agricultural Sciences, 2(6): 560-566.

Raj, A. and Mallick, R.B. 2017. Effect of integrated nutrient management on growth, productivity, quality and nutrient uptake of irrigated yellow sarson (Brassica campestris L var. yellow sarson) in older alluvial soil of West Bengal. Journal of Applied and Natural Science, 9(3): 1411-1418.

Rakshit, A., Pal , S., Meena, S., Manjhee, B., Preetipriya, Rai, S., Rai, A., Bhowmik, M.K. and Singh, H.B. 2014. Bio-priming: a potential tool in the integrated resource management. Satsa Mukkhapatra (Annual Technical Issue), 18: 94-103.

Rao, M.S.L., Kulkarni, S., Lingaraju, S. and Nadaf, H.L. 2009. Bio-priming of seeds: a potential tool in the integrated management of Alternaria blight of sunflower. Helia, 32: 107-114.

Santiago, A. de, García-López, A.M., Quintero, J.M., Avilés, M. and Delgado, A. 2012. Effect of Trichoderma asperellum strain T34 and glucose addition on iron nutrition in cucumber grown on calcareous soils. Soil Biology $\mathcal{E}$ Biochemistry, 57: 598-605.

Saravanakumar, D. and Samiyappan, R. 2007. ACC deaminase from Pseudomonas fluorescens mediated saline resistance in groundnut (Arachis hypogaea) plants. Journal of Applied Microbiology 102: 1283-1292.

Shively, G. and Galopin, M. 2013. An overview of benefit-cost analysis. Accessed online at http://www. agecon. purdue. edu/ staff/shively/COURSES/AGEC406/reviews/bca. htm.

Singh, B., Singh, K., Talwar, D., Jindal, S.K. and Sardana, V.S. 2018. Influence of bio-fertilizers on growth and yield attributing attributes in tomato. International Journal of Current Microbiology and Applied Sciences, 7(4): 3686-3694

Singh, M.P., Kumar, P., Kumar, A., Kumar, R., Diwedi, A., Gangwar, S., ... \& val Kumar Sepat, N. 2016. Effect of npk with biofertilizers on growth, yield and nutrient up take of wheat (Triticum aestivum L.) In western Uttar Pradesh condition.

Song, G.C., Choi, H.K., Kim, Y.S., Choi, J.S. and Ryu, C.M. 2017. Seed defense biopriming with bacterial cyclodipeptides triggers immunity in cucumber and pepper. Scientific Reports, 7(1): 14209.

Sudhakar, C., Rani, C.S., Knights, S. and Potter, T. 2008. Effect of inclusion of biofertilizers as part of INM on yield and economics of Safflower (Carthamus tinctorius L). In Proceedings of $7^{\text {th }}$ International Safflower Conference, Wagga Wagga, pp. 3-6.

Uddin, M.S., Amin, A.K.M.R., Ullah, M.J. and Asaduzzman, M. 2009. Interaction effect of variety and different fertilizers 
on the growth and yield of summer mungbean. AmericanEurasian J. Agron., 2(3): 180-184.

Van Hulten, M., Pelser, M., van Loon, L.C., Pieterse, C.M.J. and Ton, J. 2006. Costs and benefits of priming for defense in Arabidopsis. Proc. Natl. Acad. Sci. USA., 103: 5602-5607.
Yadav, R.S., Singh, V., Pal, S., Meena, S.K., Meena, V.S., Sarma, B.K., Singh, H.B. and Rakshit, A. 2018. Seed bio-priming of baby corn emerged as a viable strategy for reducing mineral fertilizer use and increasing productivity. Scientia Horticulturae, 241: 93-99. 
